\title{
A systemic solution to the problem of municipal solid waste management in the Kaliningrad region as a factor in sustainable development
}

\author{
Varvara Altunina, Natalia Lukyanova, and Liubov Shcherbinina \\ Immanuel Kant Baltic Federal University, 14 Alexander Nevsky St., Kaliningrad, 236041 \\ Kaliningrad, Russia
}

\begin{abstract}
This article presents a systemic approach to municipal solid waste management in the Kaliningrad region. This approach is based on innovative practices and marketing research. It will contribute to regional development in line with the principles of green economy and cross-border cooperation in the Baltic countries. An innovative ecosystem should be created in the region to reach this goal, along with a network of solid municipal waste recycling enterprises. This network should include microenterprises. The study offers a universal business model for a recycling microenterprise.
\end{abstract}

\section{Introduction}

Sustainable economic development of any region is inextricably linked to the environmental well-being of the territory, which, in turn, is determined by the success of waste management. In recent decades, global environmental problems have been given special attention at the highest level. For example, Goal 6 of the 2030 Agenda for Sustainable Development, adopted by the UN in 2015, is Clean Water and Sanitation, and Goal 11 is Sustainable Cities and Communities. Both are directly related to waste management [1]. Ecology is an important component included in the green growth strategy of the Organization for Economic Cooperation and Development, along with economic, social and technological aspects of development. One of the green economy dimensions in the document is recycling, whereas waste reduction is proposed as a source of green growth [2].

Russia has developed a legal framework for ecology, environmental protection, and waste management. In particular, the "Ecology" national project (2019-2024) has been launched. It includes several regional initiatives, such as Clean Country (Kaliningrad region) and A Complex System of Solid Municipal Waste Management (Kaliningrad region). There are national professional associations and unions, which carry out independent monitoring and recruit volunteers. Moreover, a unified system of waste management has been created. [3-5, 8]. However, the urgency of ecological and waste recycling problems does not decrease. The official 2011-2019 statistics, available to the authors, confirm this for the case of the Kaliningrad region (Fig. 1) [6]. 


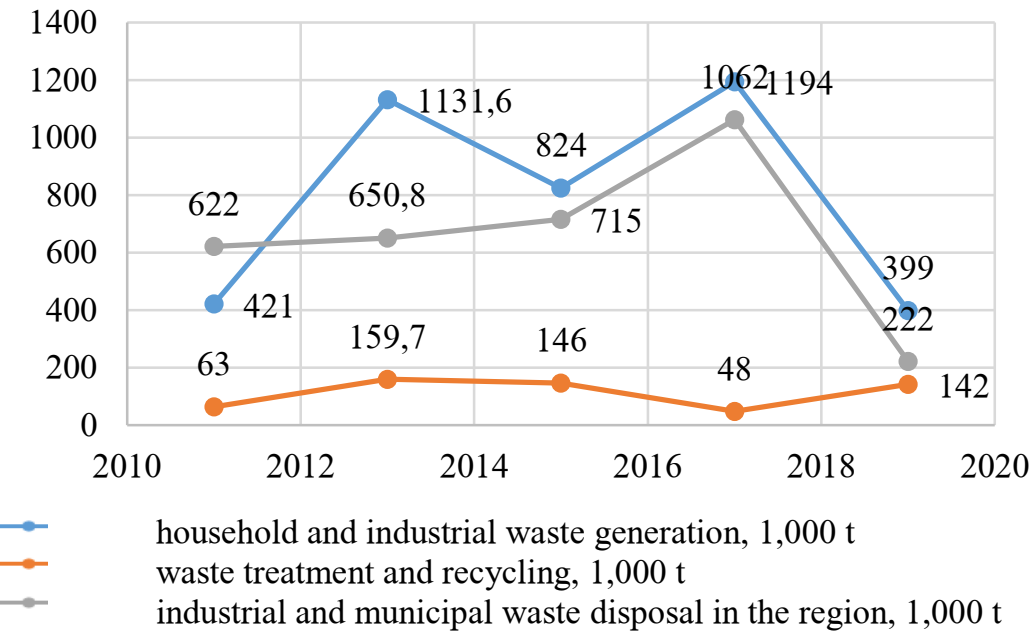

Fig. 1. Industrial and household waste management indicators in the Kaliningrad region, 1,000 $\mathrm{t}$ (according to Rosstat [6])

The so-called "rubbish reform", which started in 2019, is stalling, as publications in the media suggest. According to experts, over $99 \%$ of waste was landfilled in the Kaliningrad region before the reform [7]. Data from the regional municipal solid waste (MSW) operator show that, in 2019, 387.62 thousand tons of MSW were generated, of which 377 thousand $t$ were buried, and only $618.31 \mathrm{t}$ recycled [4]. The electronic model of the region's territorial waste management scheme available on the website of the Ministry of Nature of the Kaliningrad region offers similar data: as of 2019, 387.6 thousand t MSW was generated in the region; 384.696 thousand $t$ were landfilled; 29.07 thousand $t$ were processed; 1.454 thousand t, i.e. $0.75 \%$ of the total amount, were recycled in the region or transported to other Russian territories for recycling [8]. In 2020 the percentage of MSW utilization reached $0.65 \%$. Thus, collection and burial in landfills remain the principal waste treatment method in the Kaliningrad region.

Analysis of MSW management in the region and the development of a systemic approach to the problem, which seems particularly relevant in this situation, will constitute the object of the study. The region's innovative waste disposal ecosystem, which is a mesolevel ecosystem, and solid municipal waste management, as defined in the federal law of the Russian Federation on Industrial and Household Waste [5], are the focus of the research.

\section{Methods and approaches}

The study employs James F. Moore's ecosystem approach, which he applied to business ecosystems [9]. Today, this approach has signs of a theory in its own right.

The research also uses methods of strategic analysis of the external environment to investigate the agents of the Kaliningrad waste collection and recycling market. These methods are industry, PEST, and SPACE analysis.

A field marketing study was carried out to understand why the reform had stalled and what levers to use on participants in the regional waste management system. A survey of large regional manufacturers and marketing companies using plastic packaging for their products or selling packaged products was conducted.

The research also employs Osterwalder and Pigneur's business model canvas to build a universal business model for an MSW recycling microenterprise. 


\section{Results}

Analysis of the world's leading waste management practices shows that they rely on a similar economic model. Consumers - individuals and legal entities - pay a waste operator for waste collection on contractual terms. The operator has an agreement with the state or the municipality. The next link in the chain is usually a sorting facility, to which individuals and companies can bring waste directly. The facility charges a fee for accepting raw waste. In some countries, residents and companies must segregate waste themselves. The final link in this model is landfills and other facilities that recycle, incinerate or compost sorted waste. They also collect a fee for accepting waste and pay a tax to the municipality. The difference in tax rates for landfills and recycling facilities stimulates the development of the latter. Europe by far outperforms the US, Canada, and Australia when it comes to waste sorting. In addition, European countries such as Germany, Sweden, Austria and Belgium have minimised landfill disposal, and most of their waste is incinerated, recycled, or composted.

Why does not the model work in our country? Why does recycling account for less than $1 \%$ in the Kaliningrad region? There is no simple answer, but it seems that the cause lies in the lack of a systemic approach to the problem, a low level of environmental awareness, and insufficient social responsibility. Drawing on business ecosystem theory, we can propose several steps to improve the situation at the current stage of development of the regional waste management system. Firstly, there's a need to improve the value proposition to match the current level of technology and innovation; to refine the list of potential customers; to promote eco-consciousness and social responsibility among businesses, residents, and visitors in the region.

Secondly, it is necessary to fine-tune the current system by increasing MSW recycling capacities, embracing state-of-the-art technology and innovations, and decreasing waste volumes. Thirdly, stakeholders should be encouraged to solve the problem, and effective interactions between all the participants in this system should be organised. Fourthly, it is vital to analyse the external environment of the waste collection and recycling market, highlighting key factors in its development.

More rapid formation of eco-consciousness requires raising awareness among residents, starting from childhood. New habits and skills have to be developed. Environment-focused disciplines must be present in curricula at all levels. There is also an urgent need for regular public events dedicated to waste collection and segregation. Eco-conscious behaviour should become a norm promoted through social advertising. Such behaviour should be encouraged among residents and visitors through material and non-material incentives.

An important objective is raising eco-awareness among Kaliningrad businesses. A survey of Kaliningrad companies conducted in 2020 to identify ways to cut down on plastic packaging and switch to eco-friendly packaging showed that most local manufacturers were aware of the scale of the environmental problem. At the same time, in $95 \%$ of surveyed companies, the percentage of paper packaging was below $20 \%$, whilst $90 \%$ of respondents estimated the probability of switching to biodegradable packaging within the next few years at $20-40 \%$. The factors preventing enterprises from doing so are an undeveloped market for environmentally friendly packaging and, as a consequence, the limited availability of paper packaging suitable for the storage of products and its high price.

Kaliningrad companies named several state support, regulation, and control measures to speed up the transition to environmentally friendly packaging. These were benefits for using recycled raw materials, liability for failing to meet recycling standards, increased responsibility of the producer for packaging, more demanding recycling standards, and lower waste collection fees. The findings confirm that companies committed to green growth can function only when a comprehensive solution to this problem on the part of business, 
government and society has been provided. Green growth is achieved through creating and developing an ecosystem for waste collection, sorting, and recycling.

Figure 2 shows the scheme of a regional innovative ecosystem (a mesolevel ecosystem) for waste recycling. The ecosystem should produce a value proposition, which is the satisfaction of the environmental needs of residents, visitors, businesses, and state and municipal authorities under the condition of preservation, conservation and reproduction of regional natural, energy and human resources.

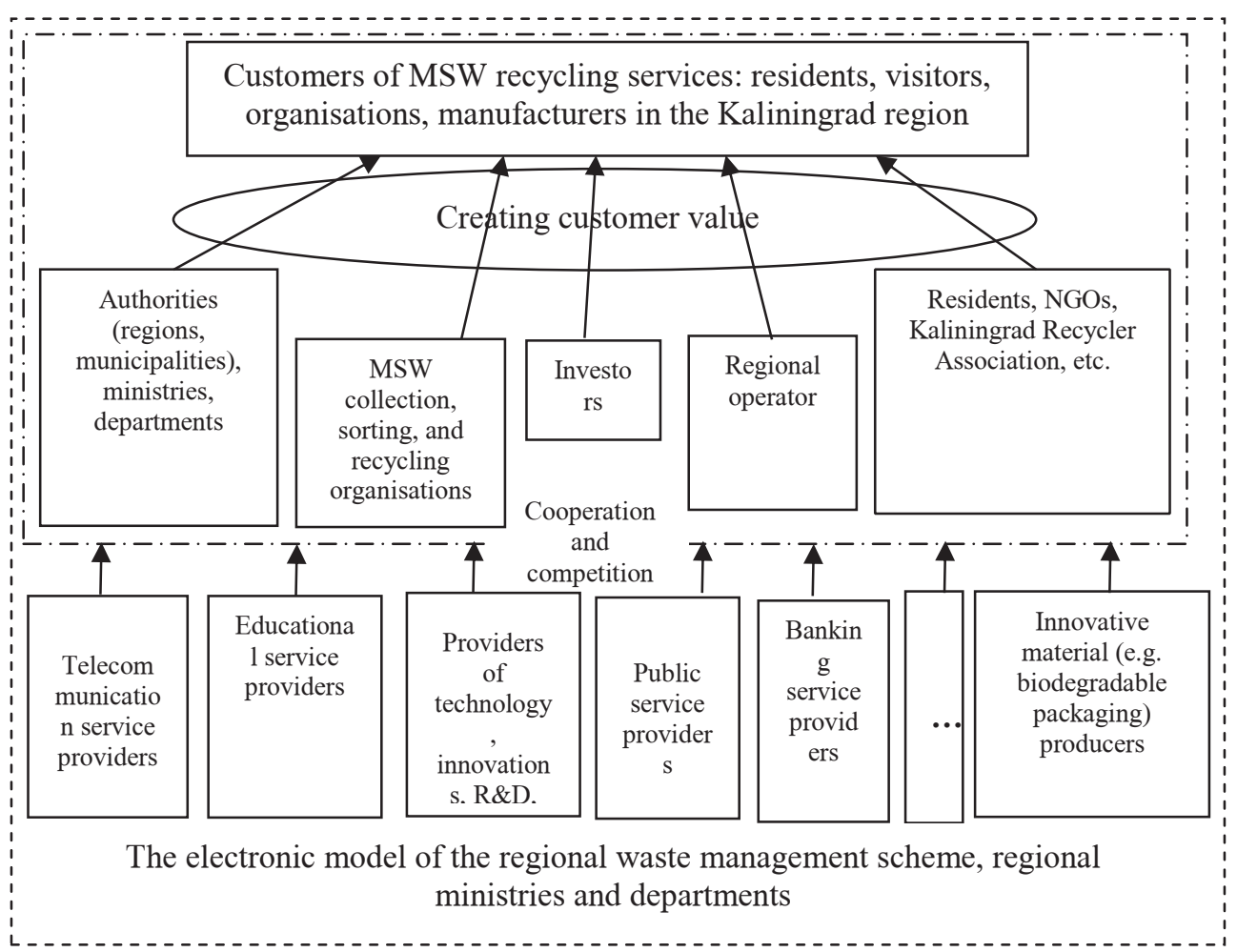

Fig. 2. A spatial ecosystem for waste collection and recycling in the region (prepared by the authors)

There are many participants in the ecosystem. The providers of sorted or unsorted waste and recyclables are residents and businesses. The latter include companies collecting clean recyclables and maintaining a separate waste collection system, waste sorting companies, companies working with certain types of recyclables, recycling plants, incineration plants, companies producing packaging from recyclables, companies producing environmentally friendly packaging. Universities and research institutions have a role in the ecosystem too. For example, the Immanuel Kant Baltic Federal University is a potential innovative platform for creating new environmentally friendly packaging materials (Fig.1 ). An information platform should bring together all participants in the ecosystem. Any supplier of sorted clean waste will be able to submit an online application, and a waste collection company will promptly process it. The platform may build on the electronic model of the current waste management scheme, which is available on the website of the regional Ministry of Nature.

Regional microenterprises may have a central role in waste collection and sorting if they succeed in creating an extensive network of partners supplying sorted recyclable waste. The potential partners of these enterprises are residents, volunteer organisations, manufacturers, wholesalers, retailers, non-profits, public utility management companies, etc. The partnership may be underpinned by the 'pay for sorted clean waste' principle. Figure 3 shows a universal 
business model for a microenterprise collecting clean and sorted recyclables. In the first stages, the currently underutilised recycling plants in Lithuania and St Petersburg are likely customers. Later, the waste may be supplied to a local recycling plant.

\begin{tabular}{|c|c|c|c|c|c|}
\hline Key partners & Key activities & \multicolumn{2}{|c|}{ Value propositions } & $\begin{array}{l}\text { Customer } \\
\text { relationships }\end{array}$ & $\begin{array}{l}\text { Customer } \\
\text { segments }\end{array}$ \\
\hline $\begin{array}{l}\text { Providers of clean } \\
\text { waste (residents, } \\
\text { volunteer } \\
\text { organisations, } \\
\text { manufacturers, } \\
\text { wholesalers, } \\
\text { retailers, non- } \\
\text { profits, etc.) }\end{array}$ & $\begin{array}{l}\text { - raising } \\
\text { awareness of the } \\
\text { services among } \\
\text { residents; } \\
- \text { receiving waste } \\
\text { collection request } \\
\text { from residents and } \\
\text { organisations; } \\
\text { - regular and on- } \\
\text { request waste } \\
\text { collection; of } \\
-\quad \text { sorting } \\
\text { collected waste at the } \\
\text { company's facilities; } \\
-\quad \text { transporting } \\
\text { clean, sorted waste } \\
\text { for recycling }\end{array}$ & $\begin{array}{l}\text { The main } \mathrm{v} \\
\text { proposition is c } \\
\text { and } \\
\text { recyclables. } \\
\text { company so } \\
\text { the custon } \\
\text { problem of the } \\
\text { of clean } \\
\text { materials". }\end{array}$ & & $\begin{array}{l}\text { Direct marketing. } \\
\text { Customers expect } \\
\text { to get well-sorted } \\
\text { clean recyclables. }\end{array}$ & $\begin{array}{l}\text { Recycling } \\
\text { companies with } \\
\text { facilities in } \\
\text { Lithuania and St } \\
\text { Petersburg faced } \\
\text { with a lack of } \\
\text { clean sorted } \\
\text { recyclables and } \\
\text { the problem of } \\
\text { unutilised } \\
\text { capacity }\end{array}$ \\
\hline \multicolumn{2}{|c|}{ Key resources: } & \multicolumn{3}{|c|}{$\begin{array}{c}\text { Channels: } \\
\end{array}$} & \\
\hline \multicolumn{2}{|c|}{$\begin{array}{l}\text { - transport; } \\
\text { - sorting facility; } \\
\text { - workforce }\end{array}$} & \multicolumn{3}{|c|}{$\begin{array}{l}\text { Direct: recyclables are delivered to the } \\
\text { customer. } \\
\text { Indirect: delivery through intermediaries } \\
\text { (microenterprises) }\end{array}$} & \\
\hline \multicolumn{3}{|c|}{ Cost structure: } & & Revenue st & ams: \\
\hline \multicolumn{3}{|c|}{$\begin{array}{ll}- & \text { material costs (payments to residents and organisations } \\
\text { for clean waste) } \\
-\quad \text { administrative expenses; } \\
-\quad \text { depreciation of machinery and equipment; } \\
-\quad \text { salaries and employer's liabilities; } \\
-\quad \text { other costs (rent of sorting facilities, etc.) } \\
\end{array}$} & \multicolumn{3}{|c|}{$\begin{array}{l}\text { About } 5,000 \text { roubles per tonne of clean, sorted, } \\
\text { and recyclable waste of the same type. } \\
\text { Payment is made by the customer immediately } \\
\text { on receipt, after inspection of the raw materials } \\
\text { for compliance with the paperwork. }\end{array}$} \\
\hline
\end{tabular}

Fig. 3. A universal Osterwald business model canvas for a small waste collection and sorting enterprise (prepared by the authors)

The external environment factors of the waste collection and recycling market in the Kaliningrad region is analysed using a PEST matrix. The analysis shows that the most significant factors positively influencing the market are the political and legal ones. These are the regulatory and legislative framework, tax policy, and state regulation and incentives for companies. Legislative regulation and incentives for effective MSW collection include tax concessions for companies using recycled raw materials; lower utility tariffs for sorted waste collection; a better procedure for segregated waste collection by Russian regions and local authorities; immediately accessible infrastructure for segregate waste collection; incentives to organisations and institutions to charge lower rates for sorted waste; liability for failure to provide segregated waste collection opportunities to the public; stricter requirements for packaging; lower recycling fees for companies using environmentally friendly packaging; support for companies producing innovative materials for biodegradable packaging.

The social factor also has a role in developing a waste management ecosystem in the region. There is a need to raise public awareness of segregated waste collection and promote eco-consciousness and social responsibility. Attention should be paid to social advertising aimed at greater environmental awareness among residents and the regional business community. It is vital to disseminate information about the principles of waste segregation, waste collection sites, and how the waste will be treated once it has been collected. 


\section{Conclusions}

This study of the Kaliningrad waste collection and recycling market, which included desk and field research of businesses responsible for a large proportion of regional MSW, has shown that the problem of waste segregation and recycling is far from solved. The problem persists despite the business community being aware of its scale and the steps taken by the regional authorities to solve it.

Solving this problem and embracing the green growth principles is possible only when the business community and residents adopt a systemic approach. It is vital to create and develop an innovative ecosystem for MSW collection, sorting, and recycling in the Kaliningrad region. All stakeholders - residents, businesses, non-profits, and authorities should be involved in the process.

The political and legal factor has a central role in creating and developing the ecosystem. It provides the necessary legal framework - a system of regulation and incentives to promote eco-consciousness in the business community. The social and cultural factors are also essential since they are the key to the promotion of ecological values among residents and visitors.

The proposed innovative ecosystem-based systemic approach to MSW management will contribute to the sustainable development of the regional economy. Development in line with the principles of green economic growth and cross-border cooperation with the Baltic countries will improve the environmental situation in the region.

\section{Acknowledgement}

The authors are grateful to master's students of the Institute of Economics, Management, and Tourism A. Davlatshina, I. Ostashchenko, and L. Davydova for their help in conducting field and desk marketing research.

\section{References}

1. SDG Indicators: Global indicator framework for the Sustainable Development Goals and targets of the 2030 Agenda for Sustainable Development. Official website of the United Nations. A/RES/71/313, 21 (2018-2020) https://unstats.un.org

2. A course for green growth: a solution for decision makers (2011) https://www.oecd.org

3. State Report on the State and Protection of the Environment of the Russian Federation in 2019, https://www.mnr.gov.ru

4. State report on the ecological situation in the Kaliningrad region in 2019 (2020) https://minprirody.gov39.ru

5. Federal Law of the Russian Federation of 24.06.1998 N 89-FZ "On Production and Consumption Waste" (with amendments and additions, effective from 14.06.2020)

6. Environmental Protection in Russia. 2020: statistical diges (2020) https://www.gks.ru

7. Rubbish Disaster (2019) https://rugrad.eu

8. Electronic model of the Kaliningrad Oblast Territorial Waste Management Scheme (2021) URL: https://minprirody.gov39.ru

9. J. F. Moore, The death of competition: Leadership and strategy in the age of business ecosystems (New York: Harper Collins, 1997) 